\title{
Review of The Role Company Supervision Mechanism in Risk Management Implementation
}

\author{
Mirna Cahyani ${ }^{1}$, Noorlailie Soewarno ${ }^{2^{*}}$ \\ 1,2 Faculty of Economics and Business, Universitas Airlangga, Surabaya, Indonesia \\ ${ }^{1}$ mirna.cahyani94@gmail.com; ²noorlailie-s@feb.unair.ac.id \\ ${ }^{*}$ Corresponding author
}

\begin{abstract}
This study reviews the supervisory mechanism carried out by the company in the implementation of risk management. This research is qualitative research with literature study method. As a result, internal auditors, audit committees and management accountants work together in supervising the implementation of risk-based audits. Internal auditors have a weak contribution because they prefer a supervisory approach so they are supported by the audit committee. The audit committee supervises the internal auditors and provides suggestions for the next audit process so that it can cover high-risk areas. Meanwhile, the external auditor supervises by ensuring whether the financial statements are presented fairly. This research contributes to expanding the study of the role of supervisory mechanisms in companies for the implementation of corporate risk management.
\end{abstract}

Keywords: internal auditor, audit committee, external auditor, risk management

\begin{abstract}
Abstrak
Penelitian ini mengulas mekanisme pengawasan yang dilakukan perusahaan dalam implementasi manajemen risiko. Penelitian ini merupakan penelitian kualitatif dengan metode studi literature. Hasilnya auditor internal, komite audit dan akuntan manajemen bekerja sama dalam mengawasi implementasi audit berbasis risiko. Auditor internal memiliki kontribusi yang lemah karena lebih menyukai pendekatan pengawasan sehingga didukung oleh komite audit. Komite audit melakukan pengawasan terhadap auditor internal dan memberikan saran untuk proses audit selanjutnya sehingga dapat mencakup area-area yang berisiko tinggi. Sedangkan auditor eksternal melakukan pengawasan dengan memastikan apakah laporan keuangan tersebut disajikan secara wajar. Penelitian ini berkontribusi untuk memperluas studi mengenai peran mekanisme pengawasan yang terdapat di perusahaan untuk implementasi manajemen risiko perusahaan.
\end{abstract}

Kata kunci: auditor internal, komite audit, auditor eksternal, manajemen risiko

\section{Cara Mengutip:}

Cahyani, M., \& Soewarno, N. (2021). Review of The Role Company Supervision Mechanism in Risk Management Implementation. Esensi: Jurnal Bisnis dan Manajemen, 11(2), 127-142. https://doi.org/10.15408/ ess.v11i2.21194. 


\section{INTRODUCTION}

The financial statement fraud scandal carried out by PT. Garuda Indonesia indicated that there was an audit failure. The Ministry of Finance described three omissions by the Public Accounting Firm (KAP), including not properly assessing the substance of the transaction (SA 315), not having received sufficient evidence to assess accounting treatment (SA 500) and not considering the facts after the date of the financial statements (SA 500, 560). Failure to obtain sufficient evidence may occur due to improper risk calculations. Audit risk can be calculated appropriately if the audit committee implements the function to ensure that the internal control structure is implemented properly and ensures that the financial statements are presented fairly (National Committee on Governance Policy, 2006).

Adoption of risk-based audit procedures will broaden the scope of internal audit activities to include integrated monitoring of all organizational activities (Selim \& McNamee, 1999). The use of structured risk-based audit procedures can also strengthen the oversight duties performed by the internal audit function and the adequacy of audit coverage of key business activities(Nor \& Hafizah, 2017). Lack of inefficient monitoring and risk assessment at strategic and operational levels will leads to inappropriate coverage of areas of strategic and operational risk exposure in the audit universe. In addition, when risk-based audit procedures are not performed consistently across all internal audit processes, the internal audit function ultimately focuses more on assessing the state of internal control than on the state of risk (Coetzee \& Lubbe, 2014; Selim \& McNamee, 1999). Adoption of risk-based auditing is highly dependent on the influence of internal monitoring mechanisms such as audit committees, internal audit attributes, and risk management and internal control systems (Nor \& Hafizah, 2017).

The role of internal audit related to risk managementessential to support the achievement of organizational goals, and consulting activities designed to add value and improve the organization's operations. This activity also helps the organization to achieve its objectives by bringing a systematic and disciplined approach to evaluate and improve the effectiveness of risk management, control, and governance processes. The core task of internal auditors with regard to risk management is to provide assurance that risk management activities have been carried out effectively in providing reasonable guarantees for the achievement of organizational goals. Some of the ways internal auditors carry out their duties are to ensure that the main risks of the business have been properly addressed and ensure that risk management and internal control activities have been running effectively. The following is an overview of the internal auditor's roles and responsibilities related to risk management, which may be part of the internal auditor's responsibilities, and which should not be his responsibility.

To maintain the effectiveness of internal audit activities, the responsibilities assigned to internal auditors regarding risk management activities must be designed so as not to interfere with their independence. This is because internal audit has an important role in supervising, monitoring, and assessing the effectiveness of the organization's internal control and risk management activities. Giving responsibility to internal auditors to determine risk appetite, establish a risk management process, and so on can create a clash of interest that has the potential to interfere with their assessment of the effectiveness of risk management. 
There are several reasons underlying the paradigm that the risk management function should collaborate with the internal audit function. Some of these reasons, includingto link audit plans and company risk assessments, as well as share other work products. This is needed to improve coordination in an effort to ensure that the main risks can be managed effectively. Share certain resources to support efficiency. The resources in question include financial, human, and time resources. Mutually enhance the competence, roles, and responsibilities of each function. Provide a consistent communication infrastructure. Assess and monitor strategic risk. Can form a deeper understanding and focused treatment to address strategic risks. Holding meetings with the risk management division can improve the internal audit function's understanding of the company's risk profile.

Figure 1. Internal Audit Responsibilities Related to Risk Management

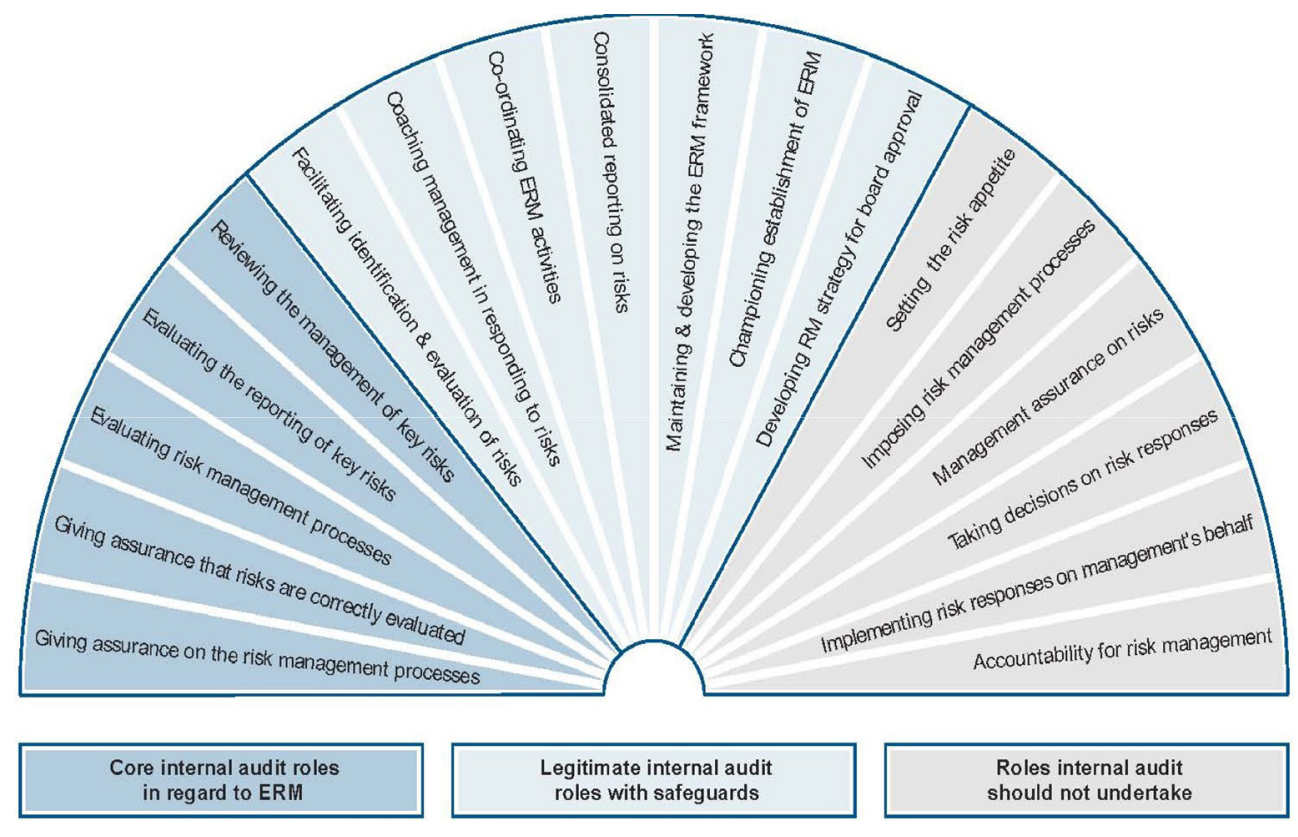

Source: The Role of Internal Auditing In Enterprise-Wide Risk Management (2009)

For COSO, risk assessment is an important activity for management and corporate internal auditors, so that internal auditors understand the processes and means for identification, assessment, measurement and risk assessment as the basis for developing internal audit procedures. COSO states that every entity faces internal risks from outside, that these risks must be identified and assessed and measured focused on securing the strategic goals of the corporation. Socio-political-economic-industrial-legal changes and changes in the operational conditions of audited companies contain risks; company management must establish mechanisms to recognize \& deal with these changes. The main basis of risk management is risk assessment.

COSO internal control is a framework outlining professional practice for establishing preferred business systems and processes that promote efficient and effective internal controls (Moeller, 2016). The COSO internal control framework is an important set or model of guidance material that companies should follow when developing their business 
processes, systems and procedures and in establishing compliance with the Sarbanes Oxley Act (SOX). As time progressed, this internal control was later developed into COSO ERM. COSO ERM is an approach that enables corporate and internal audit to consider and assess risks at all levels, whether they are in individual areas such as information technology (IT) development projects, or global risks associated with international expansion. Although the basic framework models look similar, COSO ERM is different from the COSO internal control framework. An understanding of the overall risk assessment and risk management approach, with an emphasis on COSO ERM, should be an important element in any internal auditor's CBOK. COSO ERM was launched in a similar way to the development of the original COSO internal control framework.

Risk management is a concept related to insurance where individuals or companies usually use insurance mechanisms to provide protection from these risks. Companies today face multiple risks and need help and tools to sort them all out to make rational decisions regarding costs and risks. This is a risk management process. While some people in business today typically rate an area as high, medium, or low risk and then make a quick insurance or risk protection decision based on those options, others use more sophisticated qualitative or quantitative tools to help them understand and evaluate them.

Risk analysis is also used to reduce future risk, the smaller the risk, the more likely it is to achieve corporate goals. Various legal jurisdictions also require each bank to conduct a risk assessment and publicly disclose the condition of its internal controls. This condition makes external auditors also required to make attestations about the bank's statement and the condition of the bank's internal control with the aim of protecting public deposits. The US Capital Market Authority (SEC) also requires all issuers to make Risk Assessment Reports since 1979 to protect the interests of investors. SAS 55 AICPA states that external auditors are responsible for obtaining and understanding the financial statement audit control system. Public accountants also make risk assessments related to financial statement audit planning. This is done to detect the risk of the auditor's failure to achieve the audit objectives, as well as to determine the appropriate test methods towards the audit objectives, from planning sampling to using appropriate audit techniques.

The mechanism for supervising the implementation of risk-based audits is not only carried out by the audit committee, but also by internal audit. The role of internal audit in helping to mitigate risks that threaten the company has increased. Internal audit ensures that the company has performed an effective and efficient performance, ensures that all risks can be handled and ensures that scarce internal audit resources are used optimally (IIA, 2012). Research conducted by Coetzee and Lubbe (2014) develop models to improve the efficiency and effectiveness of risk-based audit engagements. The results show that internal auditors use a risk-based approach when conducting audit engagements and prefer to use a control-based approach with more emphasis placed on high-risk areas. Castanheira et al. (2010) show that the application of risk-based audit risk is applied at the time of audit planning. Internal auditors are also more proactive in implementing ERM in smaller and more important organizations in the financial and private industries. Nor \& Hafizah (2017) conduct research on the factors that influence the implementation of risk-based auditing. Research conducted in Malaysian public companies provides evidence that there is a positive 
relationship between the reviews conducted by the audit committee on the implementation of risk-based audits, which means that the greater the involvement of the audit committee in a company, the greater the implementation of risk-based audits.

Risk-based auditing is a process, approach; methodology and attitude that is combined into one to see conceptually which parts are most problematic for the organization (Griffiths, 2012). Risk-based auditing builds on a Systems-based Audit (SBA) approach that focuses on areas of highest risk and uses a different starting point, business objectives rather than oversight. The recommendations made are also risk-evaluated to ensure maximum benefits by management. System-based audit itself is a predictable approach in systems and evaluation processes. SBA will take a vertical approach, namely reviewing activities between organizations and looking for areas where there are inconsistencies or experiencing problems.

Risk-based audit procedures underscore the importance of identifying risks inherent in strategic plans, and testing and reporting on the adequacy and effectiveness of risk mitigation procedures (Coetzee \& Lubbe, 2014; Selim \& McNamee, 1999). According to Selim \& McNamee (1999), structured risk-based audit techniques should adopt risk management practices (i.e. risk identification, risk management, and risk communication) not only in annual audit planning but also in all phases of individual audit engagements (i.e. in audit planning, audit conduct, and audit reporting). . Structured risk-based auditing may be practicable if the areas that can be audited are aligned with the activities and objectives of the organization as a whole, if risk assessment activities are carried out in the planning of annual and individual audits, and if the effectiveness of risk and control processes is tested. Appropriate implementation of risk-based auditing will enable the internal audit function to provide assurance and information on misalignments between company and business levels in terms of action plans and achievement of results.

Griffiths (2012) provides a trend of the major impetus in the internal audit function from 2002-2004. The trend shows that the encouragement of internal functions to be oriented to business risk increased from $72 \%$ in 2002 to $89 \%$ in 2004 . This is because modern internal audit expands its responsibilities by providing assurance and is a supervisory mechanism from the company's internal parties. The internal audit function is also very much needed by the company, as evidenced by a survey conducted by Griffiths (2012) shows 98\% of companies need it. Internal auditors can work closely with management to implement risk-based audits in order to optimize company value. Internal auditors can facilitate the process so that management can identify risks. Internal auditors can facilitate management to join a workshop with an external consultant. A useful workshop for management is on Control Risk Self Assessment (CSRA), which is a process for determining the assessment of projects or activities, such as a project development system or risk assessment of purchasing activities.

The company's oversight mechanism in risk-based auditing is not only carried out by internal audit but also by the audit committee. Audit committee according to Financial Services Regulation No. 55/POJK.04/2015 Regarding the Establishment and Work Implementation Guidelines The Audit Committee is a committee formed by and responsible to the board of commissioners in helping carry out the duties and functions of the board of commissioners. Everything related to the audit committee is regulated in the audit committee charter in 
accordance with Finance Number 55 /POJK.04/2015 Article 12 concerning the Establishment and Implementation Guidelines for the Audit Committee. The audit committee charter shall at least contain: (a) Duties and responsibilities and authorities; (b) Composition, structure and membership requirements; (c) Work procedures and procedures; (d) Policy for holding meetings; (e) Activity reporting system; (f) Provisions regarding the handling of complaints or reports regarding alleged violations related to financial reporting; and (g) The term of office of the Audit Committee.

The audit committee is given the responsibility to carry out proper supervision of financial statements, so that the quality of financial reports is good (Ika \& Ghazali, 2012). The audit committee can work effectively because the audit committee has a close working relationship with the external auditor so that the audit committee can assist the level of audit coverage and assurance(Hashim \& Rahman, 2011). The audit committee in its duties can help internal auditors work optimally to handle audit risk. An effective audit committee supervises the quality of financial reports and responds to all complaints related to improper accounting processes and provides recommendations for accountants who are competent and with integrity to be able to prepare financial statements that are free from material misstatement.

This research was conducted with the aim of conceptualizing the supervisory mechanism carried out by the internal auditor on the implementation of risk management. This study uses a qualitative method with a literature review of journals that examine risk management.

\section{METHOD}

This research is a qualitative research using literature study method. This study reviews the company's supervisory mechanism that can oversee the implementation of risk management. Sources of data come from journals, websites, books and company annual reports. The population of this study is journals or scientific articles published during 2009 2020. The sample used is journals or scientific articles published during 2009 - 2020 related to research topics by searching using the keywords "risk management", "internal audit ", "audit committee", "external audit". Journal searches are carried out on the Google Scholar website or using Publish and Perish software. The results of these studies are summarized and the discussion is then drawn conclusions.

\section{RESULT AND DISCUSSION}

The following are previous studies that provide results regarding the relationship between internal audit, audit committee and external audit on risk management (detail see Table 1) 
Table 1. Literature Review

\begin{tabular}{|c|c|c|c|}
\hline No. & Writer & Title & Results \\
\hline 1. & $\begin{array}{l}\text { Sarens, De } \\
\text { Beelde, and } \\
\text { Everaert } \\
(2009)\end{array}$ & $\begin{array}{l}\text { Internal audit: A } \\
\text { comfort provider } \\
\text { to the audit } \\
\text { committee }\end{array}$ & $\begin{array}{l}\text { This study uses a case study in a Belgian company. The results show that audit } \\
\text { committees seek comfort, with respect to the control environment and internal } \\
\text { control, two areas in which they face considerable discomfort. In addition to the } \\
\text { internal audit function's traditional assurance role, its involvement in improving } \\
\text { internal controls provides a significant level of comfort for the audit committee. } \\
\text { Internal auditors' unique knowledge of risk management and internal control, } \\
\text { combined with appropriate interpersonal and behavioral skills, enables them to } \\
\text { provide this convenience. In addition, their internal position, their familiarity with } \\
\text { the company, and their close relationship with people throughout the company } \\
\text { facilitates internal auditors to become a major source of comfort for audit } \\
\text { committees. In addition, the researcher found that the overall level of comfort with } \\
\text { the audit committee can be increased through collaboration between internal and } \\
\text { external audit (the so-called 'joint audit approach'). }\end{array}$ \\
\hline 2. & $\begin{array}{l}\text { de Zwaan, } \\
\text { Stewart, } \\
\text { Subramaniam } \\
(2011)\end{array}$ & $\begin{array}{l}\text { Internal audit } \\
\text { involvement in } \\
\text { enterprise risk } \\
\text { management }\end{array}$ & $\begin{array}{l}\text { This study provides evidence that most Australian companies have adopted } \\
\text { Enterprise Risk Management (ERM). Internal audit is involved in ERM assurance } \\
\text { activities, namely by reporting disturbances that occur in carrying out these ERM } \\
\text { procedures to the audit committee. However, in practice, internal auditors are } \\
\text { also involved in activities that can jeopardize their objectivity }\end{array}$ \\
\hline 3. & $\begin{array}{l}\text { Munro and } \\
\text { Stewart (2011) }\end{array}$ & $\begin{array}{l}\text { External auditors' } \\
\text { reliance on } \\
\text { internal auditing: } \\
\text { further evidence }\end{array}$ & $\begin{array}{l}\text { The study found that the relationship of internal audit reporting to the audit } \\
\text { committee and the client's business risk environment both affect the degree } \\
\text { of dependence of external audit on the control evaluation work that has been } \\
\text { carried out by internal audit. The client's business risk environment had a } \\
\text { marginally significant impact on reliance on already performed substantive test } \\
\text { work but no impact was found for reporting relationships. With regard to using an } \\
\text { IA as an assistant, both the relationship with the audit committee and the client's } \\
\text { business risk environment significantly affect the work of evaluating controls and } \\
\text { substantive tests of balances. }\end{array}$ \\
\hline
\end{tabular}

4. Ojo (2014) The Role of External Auditors in Corporate Governance: Agency Problems and the Management of Risk
External auditors can influence management's risk-taking incentives through the application of appropriate accounting policies. However, it is also important to ensure that the rules (in the event of a violation of accounting policies) are enforced simultaneously. The external auditor's responsibilities and the audit committee's role in corporate governance are fundamental complements in helping to achieve the desired corporate governance objectives. Safeguards are needed to ensure that the expertise of external auditors is maximized. Although external auditors play an important role in corporate governance, through their involvement and their examination of financial statements and accounting policies, several areas continue to pose problems. IAS (International Accounting Standards) 32 and 39 two reporting standards that relate to unbalance sheet instruments and which created problems in the cases of Parmalat and Enron, are still a challenge for the IASB. Off balance sheet instruments create problems in the aforementioned cases due to the fact that they are not reflected in the balance sheet - although they can be as large as two to three times global GDP. The IASB will also face the further challenge of reconciling these standards at a global level. Further challenges also include controversial circumstances that exist under financial reporting standards and bank regulations. Under IAS 32 what may be termed equity may not be permitted under bank regulations. The role of executive compensation in exacerbating the level of risk taking by executives, as well as the contribution of fair value to risk and uncertainty, has been demonstrated in the recent Financial Crisis. External auditors have a role to play in both situations - through engagement with banks whose involvement not only reduces examples of "short-term" behavior, but also facilitates greater monitoring and accountability in corporate governance processes. Furthermore, through the application and incorporation of appropriate accounting measures and policies, external auditors can influence financial reporting in such a way as to ensure that the measurement basis reflects the desired qualities and attributes of accounting information. External auditors have a role to play in both situations - through engagement with banks whose involvement not only reduces examples of "short-term" behavior, but also facilitates greater monitoring and accountability in corporate governance processes. Furthermore, through the application and incorporation of appropriate accounting measures and policies, external auditors can influence financial reporting in such a way as to ensure that the measurement basis reflects the desired qualities and attributes of accounting information. External auditors have a role to play in both situations through engagement with banks whose involvement not only reduces examples of "short-term" behavior, but also facilitates greater monitoring and accountability in corporate governance processes. Furthermore, through the application and incorporation of appropriate accounting measures and policies, external auditors can influence financial reporting in such a way as to ensure that the measurement basis reflects the desired qualities and attributes of accounting information. 


\begin{tabular}{ccll}
\hline No. & Writer & \multicolumn{1}{c}{ Title } & \multicolumn{1}{c}{ Results } \\
\hline 5. $\begin{array}{l}\text { Alzeban and } \\
\text { Sawan (2015) }\end{array}$ & $\begin{array}{l}\text { The impact of } \\
\text { audit committee } \\
\text { characteristics } \\
\text { on the } \\
\text { implementation } \\
\text { of internal audit } \\
\text { recommendations }\end{array}$ & $\begin{array}{l}\text { Regulators and others highlight the importance of interaction between the } \\
\text { audit committee and internal audit. One of the roles of the audit committee is } \\
\text { to review and monitor management's response to internal audit findings and } \\
\text { recommendations. This study provides empirical evidence of the relationship } \\
\text { between audit committee characteristics and perceived implementation of internal } \\
\text { audit recommendations. Using data from a survey of chief internal auditors from } \\
\text { UK-listed firms, this study finds that greater perceptions of the implementation } \\
\text { of internal audit recommendations are strongly related to the presence of } \\
\text { independent audit committee members and members' expertise in accounting } \\
\text { and auditing. The results also show that perceptions of the implementation of } \\
\text { internal audit recommendations are influenced by frequent meetings between } \\
\text { the audit committee and the chief internal auditor. }\end{array}$ \\
\hline
\end{tabular}

6. Cohen, Enterprise risk Krishnamoorthy, management and Wright and the financial (2017) reporting process: The experiences of audit committee members, CFOs, and external auditors.
The results found that governance members view ERM as having a direct relationship with the quality of the financial reporting process and the strength of internal controls. The lack of emphasis from audit committees and CFOs could provide opportunities for significant improvements in how financial reporting preparation and monitoring could benefit from taking a broader, more strategic perspective to ERM. For example, greater consideration by the CFO and audit committee of strategic aspects of ERM could result in more effective accounting estimates and/or disclosures that take into account the risks associated with, for example, the valuation of accounts receivable or inventory. A I t h o u g h members of the audit committee and CFO consider them to play an important role with respect to all ERM objectives (strategic, operational, reporting, and compliance), external auditors exhibit a weak role with respect to strategic, operational, and compliance objectives. One explanation for this finding may be that auditors view their primary responsibility as revolving around financial reporting and not involving a significant role with respect to other aspects of ERM such as corporate strategy. Another explanation may be that auditors are not sufficiently sensitive to the effects of strategic risk on financial reporting quality due to a lack of understanding or focus on the relationship between strategic risk and the financial reporting process. The experience of many CFOs and audit committee participants indicates that they find auditors to have relatively low and narrow consideration of ERM practices and strategic risk.

7. Waseem-Ul- Enterprise Risk Hameed, Ali, Management and Arif (2017) (ERM) System: Implementation Problems and Role of Audit Effectiveness in Malaysian Firms

The effectiveness of internal audit increases the level of risk management implementation. Therefore, both have a significant positive relationship with each other. Similarly, the effectiveness of external audits has a positive effect on the implementation of risk management. High quality external audit increases the level of risk management implementation. However, the low quality of internal and external audit reduces the level of risk management implementation. Thus, the effectiveness of internal and external audits has a significant positive relationship with the level of risk management implementation. In addition, the level of risk management implementation also has a strong relationship with the company's risk management system (ERM). The implementation of quality risk management has a positive influence on the company's risk management system (ERM). However,

\section{Francesco Does the}

Vallascas, Sabur Mollah, Inoard Sabur Mollah, Independence on Keasey (2017) Change After the Global Financial Crisis?

While these studies offer evidence primarily from the pre-crisis or crisis periods, in this paper we take a different perspective. In particular, we test whether the impact of board independence on bank risk-taking has changed post the global crisis as compared to the period culminated with the crisis. This research analysis is motivated by a number of post crisis regulatory reports and initiatives indicating the importance of bank boards as tools to safeguard wider stakeholder objectives and not simply the interests of shareholders (Basel Committee on Banking Supervision 2010; 2015) and by the related request of a stronger risk oversight of bank executives by independent boards. in general, to make board independence a more effective risk-mitigating mechanism post the crisis.

9. Armaya'u Alhaji Sani, Rohaida Abdul Latif, Redhwan Ahmed AlRisk Management Committee and Real Earnings dhamari (2018) Evidence from Nigeria
This study examines the empirical linked between RMC and real earnings activities through sales manipulations of listed companies in Nigeria. Managers achieved their aims by temporarily engaging in over production and offering price discount to accelerate the level of sales, such practice is more likely to post severe consequence on the future cash flow and firm value in the long-run. The study establishes that setting up RMC mitigates the real earnings in sales through abnormal production. This is an indication that establishing independent RMC will enhance the reporting quality. The study also reveals that independent directors can exercise active monitoring and deterred managers from earnings management. Therefore, this study contributes to the risk management and earnings management literature by documenting evidence that RMC is associated with lower real earnings management activities. Based on the above findings, we recommend that the Nigerian Securities and Exchange Commission should strengthen its regulation to ensure full compliance relating to RMC since only $64 \%$ of listed companies in Nigeria set up the RMC. 


\begin{tabular}{|c|c|c|c|}
\hline No. & Writer & Title & Results \\
\hline 10. & $\begin{array}{l}\text { Daniel A. } \\
\text { Amesa, } \\
\text { Christopher } \\
\text { S. Hinesb, } \\
\text { And Jomo } \\
\text { Sankarac } \\
\text { (2018) }\end{array}$ & $\begin{array}{l}\text { Board risk } \\
\text { committees: } \\
\text { Insurer financial } \\
\text { strength ratings } \\
\text { and } \\
\text { performance }\end{array}$ & $\begin{array}{l}\text { This study determine whether board risk committees add value to insurers by } \\
\text { positively impacting financial health or whether they are used solely to establish } \\
\text { legitimacy with stakeholders. Our results provide evidence related to the } \\
\text { perceptions that external evaluators have for firms implementing board-level risk } \\
\text { governance mechanisms, such as board risk committees. The results suggest } \\
\text { firms that have a board risk committee report higher financial strength ratings, } \\
\text { but only during the post-financial crisis period. This results, taken together, } \\
\text { suggest external evaluators of insurers may respond to the presence of board } \\
\text { risk committees with fairly immediate higher assessments of financial strength } \\
\text { even though it takes an average of at least five years for insurers to realize } \\
\text { positive firm performance effects. moreover, }\end{array}$ \\
\hline 11. & $\begin{array}{l}\text { Michael E. } \\
\text { Bradbury , } \\
\text { Diandian Ma, } \\
\text { And Tom Scott } \\
\text { (2018) }\end{array}$ & $\begin{array}{l}\text { Explanations for } \\
\text { Not Having an } \\
\text { Audit Committee } \\
\text { in a 'Comply } \\
\text { or Explain' } \\
\text { Regime }\end{array}$ & $\begin{array}{l}\text { Prior audit committee research has typically focused on firm characteristics } \\
\text { associated with voluntary formation or voluntary best practice. We contribute } \\
\text { to this literature by taking a 'mirror image' perspective of firms that do not have } \\
\text { audit committees. Firms that choose to have an audit committee reflect the net } \\
\text { benefits, whereas firms that do not have a committee reflect supply factors (firm } \\
\text { size and board size). Furthermore, regulators are likely to be more interested } \\
\text { in firms that do not comply with best practice guidelines than those that do. Of } \\
\text { major interest is whether the COE regime functions as intended with regard to } \\
\text { audit committees, or if the provided explanations are unrelated pretexts to avoid } \\
\text { non-compliance with best practice corporate governance. }\end{array}$ \\
\hline 12. & Jing Jia (2019) & $\begin{array}{l}\text { Does risk } \\
\text { management } \\
\text { committee } \\
\text { gender diversity } \\
\text { matter? } \\
\text { A financial } \\
\text { distress } \\
\text { perspective }\end{array}$ & $\begin{array}{l}\text { This study sets out to achieve two objectives. First, the influence of the CGPR } \\
\text { (2010) on RMCGD. The findings show that the proportion and existence of women } \\
\text { on RMCs increased with the introduction of the CGPR (2010), while controlling for } \\
\text { board gender diversity. This highlights that the CGPR (2010) has been successful } \\
\text { in increasing, not only board gender diversity but also committee gender diversity } \\
\text { in Australia. The second objective was to investigate the relationship between } \\
\text { RMCGD and a firm's probability of financial distress. It was hypothesised that } \\
\text { RMCGD may enhance risk management monitoring, thereby reducing firms' } \\
\text { excessive risk-taking behaviours, which, in turn, would lead to a reduction in } \\
\text { the likelihood of financial distress. Using the introduction of CGPR (2010) as a } \\
\text { natural setting, this study controlled for potential endogeneity problems and board } \\
\text { gender diversity and the results showed that RMCGD was associated with a lower } \\
\text { likelihood of financial distress. In addition, this study found that RMCGD was } \\
\text { particularly important when firms experienced high risk. Furthermore, this study } \\
\text { highlights the benefits of having women with financial experience on RMC. }\end{array}$ \\
\hline 13. & $\begin{array}{l}\text { Jing Jia and } \\
\text { Michael E } \\
\text { Bradbury } \\
(2020)\end{array}$ & $\begin{array}{l}\text { Risk management } \\
\text { committees } \\
\text { and firm } \\
\text { performance }\end{array}$ & $\begin{array}{l}\text { It is claimed that the RMC is a crucial corporate governance mechanism (ASX } \\
\text { CGPR, 2014). We test this assertion by examining the effectiveness of RMC } \\
\text { following the global financial crisis. We examine the association between RMC and } \\
\text { three performance measures, for } 463 \text { non-financial firms over the period 2007- } \\
2014 \text {. The performance measures we use are directly related to the functions of } \\
\text { the RMC and are the probability of financial distress, higher growth options and } \\
\text { higher firm profitability. We further distinguish between RMCs that are separately } \\
\text { constituted (SRMC) and those where an existing committee undertakes the risk } \\
\text { management activities (CRMC). This research find that firms with an RMC perform } \\
\text { better than non-RMC firms. In addition, having an SRMC results in superior firm } \\
\text { performance. SRMC have better firm performance compared to CRMC. }\end{array}$ \\
\hline
\end{tabular}

In the discussion section, the researcher will summarize the internal audit charter, external audit charter, external audit charter and the results of previous research related to the supervisory mechanism in the implementation of risk management. Every company listed on the Indonesia Stock Exchange will make disclosures including disclosures regarding the charters. The charter contains responsibilities, tenure, membership structure, policies, activity reporting system etc. The following is the discussion:

\section{INTERNAL AUDIT CHARTER}

The internal audit charter is prepared based on the Service Authority Regulation Finance No. 56/POJK.04/2015 concerning the Establishment and Guidelines for the Preparation of the Internal Audit Unit Charter. The internal audit charter is taken from the annual report 
of PT. Akasha Wira International Tbk. The following are the contents of the Internal Audit Charter: (a) Prepare and implement an annual Internal Audit plan based on risk priorities in accordance with the Company's objectives; (b) Test and evaluate the implementation of internal control and risk management system in accordance with the Company's policies; (c) Conduct inspections and assessments of efficiency and effectiveness in the fields of finance, accounting, operations, human resources, marketing, information technology, and other activities; (d) Provide suggestions for improvement and objective information on the activities examined at all levels of management; (e) Make a report on audit results and submit the report to the President Director and the Board of Commissioners; (f) Monitor, analyze, and report on the implementation of the follow-up improvements that have been suggested; ( $\mathrm{g}$ ) Cooperate with the Audit Committee; (h) Develop a program to evaluate the quality of internal audit activities that have been carried out; (i) Carry out special inspections when necessary.

\section{AUDIT COMMITTEE CHARTER}

The audit committee has the responsibility to assist the Board of Commissioners in carrying out its supervisory function. These responsibilities are outlined in the charteraudit committee based on Financial Services Authority Regulation No. 55/POJK.04/2015 concerning the Establishment and Guidelines for the Work Implementation of the Audit Committee. The following is an audit charter taken from the annual report of PT. Indo Kordsa Tbk. as follows:

a) Financial statements

1. Reviewing the Company's financial statements;

2. Reviewing and clarifying financial statements, such as financial statements to be issued, projections and considering whether they are complete and reflect appropriate accounting principles.

3. Reviewing the implementation of risk management and risk assessment of the Company and its rules, policies and processes.

4. Understand the process of making interim financial information.

b) Internal control

1. Evaluate the effectiveness of internal controls by looking at the design of implementation of policies and procedures to avoid possible errors in financial statements, misuse of assets and violations of law.

2. Understand the scope of work of internal and external auditors in reviewing internal control over the Company's financial reporting and reviewing reports on significant findings or recommendations along with management responses.

c) Internal \& External Audit

1. Together with management and the head of internal audit, they conduct a review of the internal audit charter, objectivity, authority, activities, staff and organizational structure of the Internal Audit department.

2. Review and approve the annual internal audit plan including changes to the plan.

3. Evaluate audit implementation including reviewing audit program and working papers. 
4. Ensure that there are no restrictions on the scope of Audit work, review and approve the appointment, replacement or dismissal of the Head of Internal/ External Audit.

5. Reviewing significant findings, recommendations and management follow-up on the Audit Report.

6. Resolve disputes between management and Internal/External Auditors regarding audit findings and monitor management's follow-up.

7. Reviewing the effectiveness of the Internal Audit function, including compliance with definitions, codes of ethics and standards issued by The Institute of Internal Auditors covering: aspects of integrity, objectivity, confidentiality and competence.

8. Regularly hold special meetings with the Head of Internal/External Audit to discuss issues that must be discussed specifically.

9. Approved all audit and non-audit services (including fees) to ensure that the services provided will not interfere with the independence of the external auditor.

10. Review the scope and methods of the External Auditor, including coordination with Internal Audit.

11. Together with management and the External Auditor will review the results of the audit including the difficulties encountered during the audit.

12. Reviewing the performance of the External Auditor and giving approval for the appointment or dismissal of the auditor.

13. Reviewing and confirming the independence of the External Auditor by obtaining a statement from the External Auditor regarding their relationship with the Company, including non-audit services and their implications for the Company.

14. Monitor rotation of External Audit partners as regulated by applicable laws and regulations.

\section{EXTERNAL AUDIT FUNCTION}

Referring to the annual report of PT. Indo Kordsa Tbk, the External Auditor is responsible for ensuring the integrity of the financial statements to all shareholders. The appointment of the External Auditor is the duty of the Audit Committee based on the Audit Committee Charter that stipulates that the selection and appointment process is carried out in accordance with applicable laws and regulations and the independence of public accountants.

\section{SYNERGY OF ROLES OF INTERNAL AUDITOR, AUDIT COMMITTEE, EXTERNAL AUDIT IN RISK MANAGEMENT}

Based on the results of the research above, it can be seen that the internal auditor in addition to having a direct contribution to the implementation of risk management but also supports the role of the audit committee. Internal auditors have limitations in the implementation of risk management so that there is a need for the role of the audit committee and external auditors. Subramaniam et al. (2011) results that internal auditors 
are involved in ensuring the implementation of Enterprise Risk Management (ERM). Nor \& Hafizah (2017) also provides evidence that internal audit has a function to monitor management behavior and the effectiveness of organizational systems. The results of this study are in line with the internal audit responsibilities as stated in the internal audit charter that internal audit must develop, implement, test and evaluate risk management systems in accordance with company policies. Mihret \& Khan (2013) conceptualize internal audit as a party that provides ex post assurance and consulting services to improve company efficiency and effectiveness. Coetzee (2016) also explained that internal audit should play an important role in risk-related activities to ensure that the risks that threaten the organization are reduced to an acceptable level. However, in a study conducted by Coetzee \& Lubbe (2014) stated that internal audit is reluctant to use a risk-based approach when conducting audit engagements and prefers a control-based approach in areas of high risk. Internal audit is not mature enough in carrying out the risk management strategy. Internal auditors still tend to carry out their own risk assessments rather than relying on risk management processes. Recommendations given by internal auditors are very important considerations so that they can mitigate the magnitude of risk in the company.

The role of internal auditors in overseeing the course of risk management makes internal auditors have a threat to their objectivity, so it is necessary to have an audit committee role in order to maintain their objectivity (Subramaniam et al., 2011). The audit committee has a role to review and monitor management's response to internal audit findings and recommendations (Alzeban \& Sawan, 2015). Greater perceptions of the implementation of internal audit recommendations are strongly related to the presence of independent members of the audit committee and the expertise of members in accounting and auditing. The results also show that perceptions of the implementation of internal audit recommendations are influenced by frequent meetings between the audit committee and the chief internal auditor Nor and Hafizah (2017) provide evidence of the importance of proactive audit committee members with the presence of a strong risk culture in agency matters. A proactive audit committee requiring more information on related issues is more likely to influence the conduct of a risk-based audit. The audit committee must have the ability to communicate or interact comfortably on business issues, so that it can regulate governance practices and be more critical in handling non-routine activities (Turley \& Zaman, 2004). A proactive audit committee is more involved in reviewing internal audit activities. Coetzee (2016) also stated that the audit committee should investigate the organization's risk management structure and the role played by internal audit, which could be improved if an appropriate level of coordination is established. For the audit committee, the role of the internal auditor can provide comfort for the audit committee in carrying out its supervisory function (Sarens et al., 2009). The internal auditor's unique knowledge of risk management and internal control, combined with appropriate interpersonal and behavioral skills, allows the internal auditor to provide this convenience. An equally important oversight mechanism is the external auditor's role. External auditors have a role to ensure that the financial statements are presented fairly and free from material misstatement caused by the company's undetected risk. External auditors in carrying out their work are supported by documents owned by internal auditors. Munro and Stewart (2011) gives the result that 
there is a relationship between internal audit and the audit committee and the client's business risk environment both affect the level of dependence of external audit on control evaluation work that has been carried out by internal audit. Internal auditors act as assistants whose work can be relied on by external auditors so that substantive testing that takes a long time can be minimized. Waseem-Ul-Hameed et al. (2017) also found that effective internal and external auditors have a positive effect on risk management implementation. High quality external audit increases the level of risk management implementation. External auditors can influence management to apply appropriate accounting standards and ensure that these standards are implemented properly so as to optimize the implementation of risk management (Ojo, 2014). The existence of an audit committee can be a medium for this to be achieved. Figure 2 show the above description.

The importance of risk management is closely related to the quality of financial reporting that will be submitted to the public. Cohen et al. (2017) shows that the strength of internal control can increase the effectiveness of ERM so that the quality of financial reports will be better. The audit committee through strategic aspects of ERM can produce more effective accounting estimates and disclosures related to risk considerations such as debt and inventory assessments. External auditors do not have a direct role in the company's strategic, operational and compliance objectives, but the presence of external auditors can improve the quality of financial reports which are important instruments for stakeholders.

Figure 2. Synergy of Supervisory Mechanisms in Risk Management

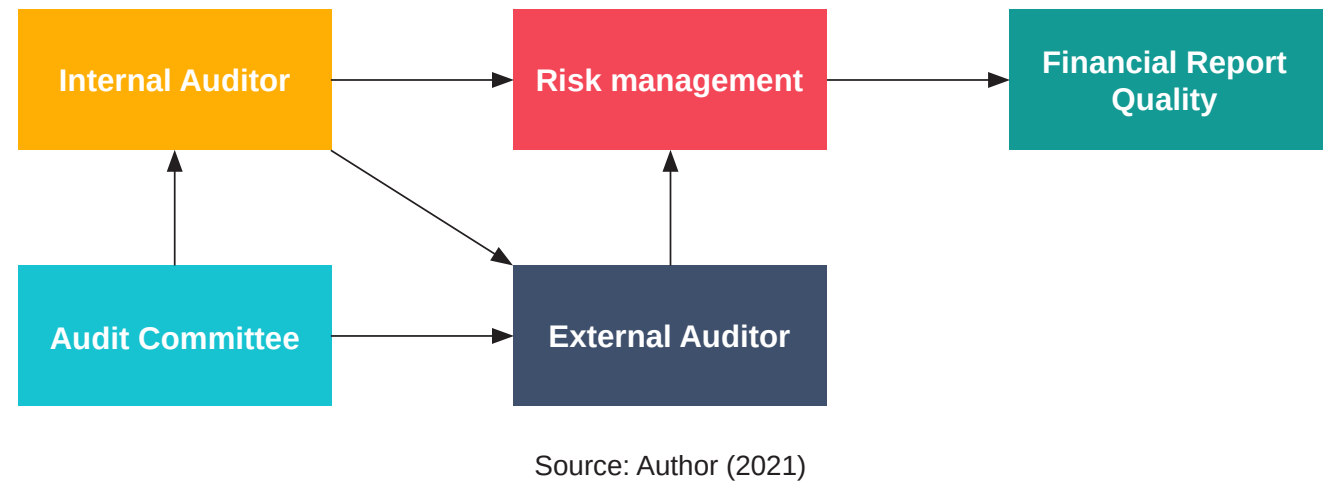

\section{CONCLUSION}

This study aims to conceptualize the supervisory mechanism in the implementation of corporate risk management. The summary results from several previous studies show that internal auditors, audit committees and external auditors synergize in supervising the implementation of risk-based audits and mitigating the risks owned by the company. Internal auditors have limitations in carrying out risk management due to their limited role, which can only provide recommendations regarding the parts that need supervision. In addition, internal auditors who have a role to oversee the course of ERM are vulnerable to the threat of objectivity. The audit committee has a role to review and monitor management's response to internal audit findings and recommendations. The existence of a committee can assist internal auditors in carrying out supervision related to ERM, especially if the audit 
committee is a pro. The audit committee can also provide facilities for internal auditors to consult with external parties to improve their ability to carry out their duties with a riskbased approach. An avid audit committee can provide oversight for internal auditors and will provide input for internal audit planning and ensuring adequate audit coverage for key areas. Meanwhile, the external auditor who is responsible for ensuring that the financial statements are presented fairly is greatly helped by the results of the work carried out by the internal auditor. The work of the internal auditors is reliable so that the external auditors have sufficient confidence that the internal auditors have controlled these parts which causes substantive tests to be minimized.

This research contributes, firstly to the academic field because it can add insight into the best supervisory mechanisms so that risk-based audits can be implemented properly. Second, the company can provide recommendations on how to optimize the monitoring mechanism, both carried out by the audit committee and the internal auditor function, so that risk-based audits can be carried out at every stage of the audit so that risk can be greatly minimized. This study builds the concept of synergy between the supervisory mechanisms owned by the company, so that for further research, quantitative testing can be carried out in order to determine the effect of the supervisory mechanisms on risk management. This study still has limitations, because it only reviews the impact of risk management on financial statements. Further research can conduct research on the impact of risk management for the company because it is suspected that if the company can minimize the risk then the company's operational activities can run well and can improve company performance.

\section{REFERENCES}

Alzeban, A., \& Sawan, N. (2015). The Impact of Audit Committee Characteristics on The Implementation of Internal Audit Recommendations. Journal of International Accounting, Auditing and Taxation, 24, 61-71. https://doi.org/10.1016/j.intaccaudtax.2015.02.005

Ames, D. A., Hines, C. S., \& Sankara, J. (2018). Board Risk Committees: Insurer financial strength ratings and performance. Journal of Accounting and Public Policy, 37(2), 130145. https://doi.org/10.1016/j.jaccpubpol.2018.02.003

Bradbury, M. E., Ma, D., \& Scott, T. (2019). Explanations for Not Having an Audit Committee in a 'Comply or Explain' Regime. Australian Accounting Review, 29(4), 649-662. https:// doi.org/10.1111/auar.12241.

Castanheira, N., Lima Rodrigues, L., \& Craig, R. (2010). Factors Associated with The Adoption of Risk Based Internal Auditing. Managerial Auditing Journal, 25(1), 79-98. doi:10.1108/02686901011007315.

Coetzee, P. (2016). Contribution of Internal Auditing to Risk Management. International Journal of Public Sector Management, 29(4), 348-364. https://doi.org/10.1108/ IJPSM-12-2015-0215.

Coetzee, P., \& Lubbe, D. (2014). Improving the Efficiency and Effectiveness of Risk Bassed Internal Audit Engagements. International Journal of Auditing, 18(2), 115-125. https:// doi.org/10.1111/ijau.12016. 
Cohen, J., Krishnamoorthy, G., \& Wright, A. (2017). Enterprise Risk Management and The Financial Reporting Process: The Experiences of Audit Committee Members, CFOs, and External Auditors. Contemporary Accounting Research, 34(2), 1178-1209.

de Zwaan, L., Stewart, J., \& Subramaniam, N. (2011). Internal Audit Involvement in Enterprise Risk Management. Managerial Auditing Journal, 26(7), 586-604. https:// doi.org/10.1108/02686901111151323.

Griffiths, M. P. (2012). Risk-Based Auditing. United Kingdom: Gower Publishing, Ltd.

Hashim, U. J. B., \& Rahman, R. B. A. (2011). Audit Report Lag and the Effectiveness of Audit Committee Among Malaysian Listed Companies. International Bulletin of Business Administration, 10, 50-61.

IIA, I.o. IA (2012). International Professional Practices Framework. Retrieved from https:// na.theiia.org/standards-guidance/recommended-guidance/pages/newly

Ika, S. R., \& Ghazali, N. A. M. (2012). Audit Committee Effectiveness and Timeliness of Reporting: Indonesian Evidence. Managerial Auditing Journal, 27(4), 403-424.

Jia, J. (2019). Does Risk Management Committee Gender Diversity Matter? A Financial Distress Perspective. Managerial Auditing Journal, 34, (8), 1050-1072. https://doi. org/10.1108/MAJ-05-2018-1874

Jia, J., \& Bradbury, M. E. (2020). Complying with Best Practice Risk Management Committee Guidance and Performance Journal of Contemporary Accounting \& Economics, 16(3), 1-12. https://doi.org/10.1016/j.jcae.

Mihret, D. G., \& Khan, D. (2013). The Role of Internal Auditing in Risk Management. Paper presented at the Seventh APIRA Conference (Paper No. K224).

Moeller, R. R. (2016). Brink's Modern Internal Auditing: a Common Body of Knowledge. New Jersey: John Wiley \& Sons.

Munro, L., \& Stewart, J. (2011). External Auditors' Reliance on Internal Auditing: Further Evidence. Managerial Auditing Journal, 26(6), 464-481. https://doi.org/10.1108/ 02686901111142530.

Nor, Z. A, \& Hafizah. (2017). Factors Influencing The Implementation of Risk-Based Auditing. Asian Review of Accounting, 25(3), 361-375. https://doi.org/10.1108/ARA-10-2016-0118

Ojo, M. (2014). The Role of External Auditors in Corporate Governance: Agency Problems and The Management of Risk. MPRA No. 28149.

Sani, A. A., Latif, R. A., \& Al-dhamari, R. A. (2018). Risk Management Committee and Real Earnings Management Through Sales: Evidence from Nigeria. Journal of Advanced Research in Business and Management Studies, 12(1), 62-69.

Sarens, G., De Beelde, I., \& Everaert, P. (2009). Internal Audit: A Comfort Provider to The Audit Committee. The British Accounting Review, 41(2), 90-106. https://doi.org/10.1016/j. bar.2009.02.002.

Selim, G., \& McNamee, D. (1999). The Risk Management and Internal Auditing Relationship: Developing and Validating a Model. International Journal of Auditing, 3(3), 159-174.

Turley, S., \& Zaman, M. (2004). The Corporate Governance Effects of Audit Committees. Journal of Management and Governance, 8(3), 305-332. 
Vallascas, F., Mollah, S., \& Keasey, K. (2017). Does The Impact of Board Independence on Large Bank Risks Change After The Global Financial Crisis?. Journal of Corporate Finance, 44, 149-166. https://doi.org/10.1016/j.jcorpfin.2017.03.011.

Waseem-Ul-Hameed, FH, Ali, M., \& Arif, M. (2017). Enterprise Risk Management (ERM) System: Implementation Problems and Role of Audit Effectiveness in Malaysian Firms. Asian Journal of Multidisciplinary Studies, 5(11), 34-39. 